\title{
The Effect of Organizational Factors on Performance Measurement in Indonesia Local Governments
}

\author{
Submitted 08/05/20, 1st revision 30/07/20, 2nd revision 10/08/20, accepted 30/09/20
}

\begin{abstract}
Khoirul Aswar ${ }^{1}$, Lovina Eka Putri ${ }^{2}$, Ermawati $^{3}$
Abstract:

Purpose: This research begins with a problem dealing with the inability of many local governments in Indonesia to compile a Government Agency Performance Accountability Report or LAKIP. The problem transpires because many local governments have not been able to measure performance using applicable standards. This research aims to find out the local government's efforts to measure performance according to the organizational factors of local government in Indonesia.

Approach/Methodology/Design: Data collection in this study was based on the structured questionnaire sent to 44 respondents who have been the Head of the Planning Subdivision that has compiled LAKIP in Bekasi city, Indonesia. The sampling methodology used in this study is a census method. The hypothesis testing is based on the Structural Equation Modelling by SmartPLS.

Findings: The results indicate that the resources have a significant positive relationship with the local government performance measurement. Meanwhile, technical knowledge and management commitment do not have a significant relationship with the local government performance measurement.

Practical Implications: The findings imply to the local government expected to maintain the principles of behavior and ethics by existing standards to carry out the preparation of LAKIP and provide a picture for the local government in measuring performance based on organizational factors.

Originality/Value: The study originally examines the effect of resources with the local government performance measurement.
\end{abstract}

Keywords: Performance measurement, organizational factors, institutional theory, local government.

JEL classification: M41, M48, M53.

Paper Type: Research article.

\footnotetext{
${ }^{I}$ Department of Economics and Business, Universitas Pembangunan Nasional Veteran Jakarta, Indonesia, E-mail: khoirulaswar@upnvj.ac.id;

${ }^{2}$ Department of Economics and Business, Universitas Pembangunan Nasional Veteran Jakarta, Indonesia, E-mail: oolovinaoo@gmail.com;

${ }^{3}$ Department of Economics and Business, Universitas Pembangunan Nasional Veteran Jakarta, Indonesia, E-mail: ermawati@upnvj.ac.id;
} 


\section{Introduction}

Since the last decade, several countries have practically reformed public sector services in which the reform is possible to be associated with the movement to implement New Public Management (NPM) or New Public Management (Aswar, 2019). NPM focuses on both decentralization and modernization of public sector services. In this modern era, the main objective of public sector services is to provide good public services. The government's efforts to improve the old government system and perform good governance is understood as the implementation of Law No. 32 the year 2004 concerning Regional Government and Law No. 33 of the year concerning Fiscal Balance between the Central Government and Regional Governments shows. Imawan (2005) states that structurally good governance is presented as a slim and lean structure by avoiding the complexity of the network and realizing modern organizational principles dealing with a clear division of tasks and delegation of authority.

One of the government's efforts in realizing good governance is to implement the principle of accountability. Accountability showing both an increase in government agencies' performance and positive changes in its employees' behavior is considered a good one. Improved government agencies' performance cannot be realized if there is no good management encouraging agencies' efforts to improve their performance. Performance-based management is to increase government agencies (Propper and Wilson, 2003; Kloot, 1999). Presenting a follow-up, the Government has issued Presidential Instruction Number 7 the year 1999, which concerns about Performance Accountability of Government Agencies with the issuance of the Decree of the People's Consultative Assembly of the Republic of Indonesia Number XI/MPR/1998 focusing on the Implementation of a Clean and Corruption, Collusion and NepotismFree State as well as Law Number 28 the year 1999 dealing with the Implementation of a Clean and the Free State of Corruption, Collusion and Nepotism. The Presidential Instruction requires each Government Institution starting from an independent Echelon IV Officer and above to take responsibility for implementing its main duties and functions and the authority to use resources and policies entrusted based on the previously formulated strategic planning. The government requires all government agencies to prepare a Government Agency Performance Accountability Report (LAKIP) as the final product of the Government Institution Performance Accountability System (SAKIP). It describes a government agency's achieved performance to implement the programs and activities financed by the State Revenue Expenditures/Expenditure on Regional Expenditure.

Carrying out these performance measurements, the Indonesian government has also encountered several challenges. One of which is the inability of many government agencies to prepare a good LAKIP. Based on the report, it generally does not inform agencies' success to use appropriate performance measures. Instead, the report is more about the activities done, which do not focus on the performance of the improvements. This condition is also found in Indonesia. Research conducted by 
Jurnali and Siti-Nabiha (2015) reveals that even after years of evaluation of the implemented system, it does not present good results or achieve the targets.

Table 1. Performance Evaluation of Provinces in Indonesia with Good Grades

\begin{tabular}{|l|c|c|}
\hline \multicolumn{1}{|c|}{ Administrative Tiers } & $\mathbf{2 0 0 9}$ & $\mathbf{2 0 1 2}$ \\
\hline Provinces & $3.7 \%$ & $75.75 \%$ \\
\hline Cities/Districts & $1.16 \%$ & $24.20 \%$ \\
\hline
\end{tabular}

Source: Own study.

Based on performance evaluations in 2012, $75.75 \%$ of provinces received good grades (CC or higher) but only $24.20 \%$ of districts or cities received good grades. Considering this fact, more attention should be drawn for the district/city level. The central government ought to facilitate and guide the local government agencies to improve their performance. The improved performance is measured/assessed by the performance measurements. Kloot (1999) indicates a performance measure designed to measure the level of the achieved objectives, community satisfaction, service performance, and comparison between institutions. It includes information on resource efficiency in producing goods and services, quality of goods and services, comparison of results of activities with targets, and the effectiveness of actions to achieve the goals.

The development and the use of performance indicators are expected to be influenced by organizational factors. They become the extent to support the implementation by conducting certain training on related knowledge (Shields, 1995; Cavalluzzo and Ittner, 2004). From this perspective, institutional theory is an example on how to reveal that organizations formed due to institutional environmental pressures in the form of language and symbols explaining the existence of organizations. It is also accepted as norms in organizational concepts (DiMaggio and Powell, 1983) in its application. Based on the above explanation, the purpose of this research is to investigate the extent of local government efforts in measuring performance based on organizational factors which is technical knowledge, management commitment, and resources.

\section{Literature Review and Hypotheses}

\subsection{Theoretical Framework}

Institutional theory is chosen for this research because it focuses on developing sociological insights into institutions as well as the way they interact and their effects on people (Scott, 1987). This theory further delves into the social structure (Scott, 2004) and it has been widely used to explain phenomena and to provide complex and rich insights into the environment of public sector organizations (Van Helden, 1995 in Wijaya and Akbar, 2013). According to Scott (1995), there are three pillars namely institutional, regulative, normative and cognitive. Gudono (2012) explains that not all experts agree with Scott's idea related to institutional pillars. 
The relationship, the sequence and the abilities of each pillar need to be considered. In addition, there are concepts which need further explanation related to the mechanisms which exist in those three. It is the concept of isomorphism. DiMaggio and Powell (1983) identify three mechanisms of isomorphism mentioned as coercive, mimetic and normative isomorphism mechanisms.

\subsubsection{Technical Knowledge}

Technical Knowledge is needed by employees to carry out their duties. This forces organizations to provide training and ensures that employees get the training. Yang and Hsieh (2007) has proven that it is an urge to provide technical training to the performance measurement specialists and managers (Hatry, 1999; Newcomer et al., 2002). This model presents the fact that technical training is far more essential to explain adoption than effectiveness. This is also because of the fact that the current technical training program in Taipei focuses mostly on technical knowledge on how to design indicators and how to set up the system. Thus, this becomes a logical assumption that there is a positive relationship between increased technical knowledge and performance measurement.

H1: There is a positive relationship between technical knowledge and the local government performance measurement.

\subsubsection{Management Commitment}

Implementation of performance management systems in government needs improvements in the processes, staff, structure or even organizational culture. In the system implementation previous study found that management have a significant impact on the accrual accounting (Aswar and Saidin, 2018; Aswar and Saidin, 2018b). These kinds of changes tend to create resistance within the organization. In terms of developing and using success metrics such as organizational change, it is crucial to build high-level engagement among top managers and gather support from employees and middle managers (Fernandez and Rainey, 2006; Rainey, 2003). The effectiveness of creativity in performance measurement seems to be a serious factor in the management commitment.

H2: There is a positive relationship between management commitment and the local government performance measurement.

\subsubsection{Resources}

Resources arise from the pressure generated by the organization which ought to have adequate resources to achieve the organization goals according to institutional theory. This is in line with institutional theory of mimetic isomorphism in which the pressure arises because of the behaviour of imitating other organizations which have the ability to provide adequate organization resources. Resources are all things used to support work processes to achieve goals. The availability of appropriate resources regulates the effective and reliable implementation of each performance measurement (Julnes and Holzer, 2001). Furthermore, Wang and Berman (2000) 
shows a significant and positive relationship between financial resources and the use of performance measurement. Performance measures are often found in countries with adequate financial resources compared to countries without adequate financial resources. According to the explanation, the next hypothesis is:

H3: There is a positive relationship between resources and the local government performance measurement.

\section{Methods}

The sample is chosen related to performance measurements produced by regional apparatus organizations which are able to provide necessary information. Samples taken for this research are all the Head of the Subdivision of Planning in the Regional Apparatus Organization of the City Government of Bekasi City. Based on certain criteria for samples, there are 44 respondents who have been the Head of Planning Subdivision that has compiled LAKIP. Researchers took the sample to represent the overall problems related to performance measurement at the local government level at the city government level. This is because not all city governments serve adequate quality performance measurements. There is a paradigm mentioning that local governments, especially city governments, only focus on measuring inputs rather than outputs.

Table 2. List Of Regional Government Organization of Bekasi

\begin{tabular}{|l|c|}
\hline \multicolumn{1}{|c|}{ Regional Government Organization } & No. of Regional Government \\
\hline Civil Service Police Unit & 1 \\
\hline Inspectorate & 1 \\
\hline Local Agencies & 21 \\
\hline Regional Committee & 6 \\
\hline Regional People's Representative Council Secretariat & 1 \\
\hline Regional Public Hospital & 1 \\
\hline Regional Secretariat & 12 \\
\hline Sub-District & 44 \\
\hline Total Number of Head Subdivision Planning & \\
\hline
\end{tabular}

Source: Own calculations.

Performance measurement is the process of gathering, analysing, and / or reporting information related to the performance of individual groups, institutions, systems or elements (Behn, 2003). Performance measurements as measured by items used by Cavalluzzo and Ittner (2004) and adopted from Akbar, Pilcher and Perrin (2012). Technical knowledge is knowledge held by employees to carry out their duties. It is measured by statement items conducted Cavalluzzo and Ittner (2004). Management commitment is a concrete form of loyalty to see the extent to which management pays close attention, contributes ideas, and is responsible for institutional goals. Management commitment adopting Cavalluzzo and Ittner (2004). Furthermore, resources are all things possibly used to support work processes in achieving targets. 
Effective and accurate implementation of each performance measure depends on the availability or unavailability of adequate resources (Julnes and Holzer, 2001). This research was adopted with a modification from Julnes and Holzer (2001). Resources are measured by adapted by Akbar et al. (2012).

\section{Results}

\subsection{Descriptive Analysis}

Pallant (2005) states that descriptive statistics are used to categorize research samples and check statistical assumptions which do not meet the requirements in the research variables. In this research, most of the statistical measurements used to explain the data using the mean and standard deviation. This study delivers a questionnaire with a 5-point Likert scale. Muhammad, Maheran, Jantan and Taib (2010) suggest to use the mean to explain the research data characteristics. A mean value of less than 2.33 is low; a mean value of 2.33 to 3.67 is moderate and a mean value of more than 3.67 is high. Nonetheless, the entire variables are regarded as a good because all of them are within the range of high scores. The results of the analysis related to descriptive statistics in this research include:

Table 3. Mean and Standard Deviation

\begin{tabular}{|l|c|c|c|}
\hline \multicolumn{1}{|c|}{ Variables } & Total Questions & Mean & Std. Dev \\
\hline Performance Measurement (PM) & 7 & 4,34 &, 181 \\
\hline Technical Knowledge (TK) & 5 & 3,91 &, 093 \\
\hline Management Commitment (MC) & 3 & 3,87 &, 335 \\
\hline Resources (R) & 5 & 3,98 &, 169 \\
\hline
\end{tabular}

Source: Processed data.

\subsection{Results}

$\mathrm{T}$ test or partial test is used to examine the effect of the relationship among independent variables namely technical knowledge (TK), management commitment (MC) and resources (R) on the dependent variable on performance measurement $(\mathrm{PM})$. Where it is known as t-table $=2.02267$ which is obtained from formulas such as $\mathrm{df}=\mathrm{n}-\mathrm{k}$ or $\mathrm{df}=44-5=39$. Then, it is associated with a $5 \%$ confidence level or 0.05 .

Table 4. PLS Path Algorithm and Bootstrapping

\begin{tabular}{|c|c|c|c|}
\hline Variable & Path Coefficients & T-Values & P-Values \\
\hline TK $\rightarrow$ PM & $-0,073$ & 0,534 & 0,594 \\
\hline MC - PM & 0,164 & 1,117 & 0,265 \\
\hline R $->$ PM & 0,309 & 2,377 & 0,018 \\
\hline
\end{tabular}

Source: Processed data. 
Table 4 above presents the results of the technical knowledge on performance measurement. The results explain that technical knowledge does not have a significant effect on performance measurement. The results are supported by Gerrish (2015) mentioning that the results of technical knowledge do not affect significantly on performance measurement in several studies carried out in the United States. However, the results of this research are not in accordance with Yang and Hsieh (2007) in Taipei, Taiwan. They suggest that technical knowledge is able to increase organizational members' rational knowledge about performance measurement as emphasized by Julnes and Holzer (2001). It has a greater impact on the adoption than on the implementation. This hypothesis is rejected. This is because the knowledge about LAKIP preparation is usually obtained from guidelines given by the central government which is not specific to the technical knowledge. The Head of the Planning Subdivision assisted by his staff only as work demands. They do not work because of the intention to serve the profession that is currently occupied.

Thus, the desire to enrich themselves with knowledge of technical performance measurement is considered relatively less. Another cause related to this hypothesis is declined due to the lack of training given to the Head of Planning Subdivision in the realization of compiling LAKIP so that they only relied on the guidelines given by the central government. Besides, problems such as lack of knowledge and skills in implementing the system for measuring existing performance. Improvements that have been made by the Regional Government Organizations of the City Government of Bekasi regarding knowledge in preparing LAKIP are by organizing training conducted in conjunction with the Work Plan Discussion Meeting where the meeting also serves as a training ground on how to prepare LAKIP and also a place of discussion among Head of Planning Subdivision in preparing LAKIP.

Furthermore, the results of testing the management commitment on performance measurements show that management commitment does not have a significant effect on performance measurement. This study in line with Moynihan (2005) who agrees that management commitment does not have a significant influence on performance measurement in public organizations in the United States. However, the results of not consistent with Cavalluzo and Ittner (2004) who reveal that management commitment has a significant effect on performance measurement. Management commitment expected to influence the employees to be responsible for the results and use the information for decision-making. This hypothesis is rejected. This is because considering the State Civil Apparatus only undergo their work due to work demands so that commitment to achieve organizational goals is considered less important. They have the burden borne by each field which is equally heavy.

The results related to the lack of encouragement to do things out of their duties can accelerate the process of achieving organizational goals. Other causes related to this hypothesis are declined as seen from Moynihan (2005) which suggests that the adoption of performance measurement is done because of external pressure. It is not from internal management so that employees may not be ready for a change. 
Improvements to increase the commitment of workers to a job have been made by the Regional Government Organization of the City of Bekasi. It is by introducing new ways in the work system. Every State Apparatus in the Bekasi City Government will have work points to do. If they do not perform well, they will get sanctions. This has proven to change many individual performances to be more productive according to their portion. This delivers a good impact on the commitment of each State Civil Apparatus to jointly improve the performance for the achievement of organizational goals.

Lastly, the results of testing the resources on performance measurement indicate that resources have a significant effect on performance measurement. This is consistent with Julnes and Holzer (2001) who convey that resources have a positive influence on performance measurement at the Association of Government Finance Officers, International City/ Regency Management Associations, and the National Association of College and University Business Officials in the United States. Wang and Berman (2000) also suggest that resources have a positive influence on performance measurement in their research in 856 provinces in the United States. Akbar et al (2012) finds that resources have a significant influence on performance measurement in all local governments throughout Indonesia. The results strengthened by institutional theory especially mimetic isomorphism, which suggests that there is a desire to imitate other better organizations to be able to achieve organizational goals. The availability of adequate resources, it is expected to be able to support all activities in performance measurement which can also have a good influence on local governments.

\section{Conclusion}

After conducting research and a series of hypothesis testing related to the influence of technical knowledge, management commitment, and resources on the measurement of local government performance, the following conclusions are made: Technical knowledge does not have a significant effect on performance measurement. It means that the Head of Planning Subdivision has a low understanding to measure performance so that the level of ease of performance measurement decreases. Management commitment does not have a significant effect on performance measurement. It means that the Head of Planning Subdivision has a low commitment dealing with performance measurements, the level of ease of performance measurement decreases. Resources have a significant influence on performance measurement. It means resources have a significant influence on performance measurement. The higher the resources provided, the higher the increase of the level of ease for performance measurement.

In this research, there are several limitations which affect the results. The limitations include that this research only used samples from one local government, Bekasi City Government. This is due to the limited time and cost of the researchers so that they cannot reach the Head of Planning Subdivision in other areas. The majority of the 
Head of Planning Subdivision in this research aged 40-49 years old with a total of 19 people and > 50 years old with a total of 17 people. However, the Head of the Planning Division, aged 30-39 years old, is still very few, only 8 people. In connection with the conclusions obtained in this research, researchers provide some recommendations for future researchers which are expected to be useful. The Head of Subdivision Planning of the Regional Organization, the City Government of Bekasi is expected to be able to maintain the principles of behaviour and ethics in accordance with existing standards to carry out the preparation of LAKIP and also to be responsible for any assignments entrusted to maintain public trust. Future researchers are expected to be able to use other variables which affect performance measurements such as productivity, internal accountability, management innovation, and reward expectation that can be used as variables. Furthermore, further research is expected to increase the number of research objects and research respondents so that the results are more valid. Then, the future researchers should also pay attention to the number of questionnaires used so that the number of constructs or statements can be more in-depth.

\section{References:}

Akbar, R., Pilcher, R., Perrin, B. 2012. Performance measurement in Indonesia: the case of local government. Pacific Accounting Review, 24(3), 262-291.

Aswar, K., Saidin, S.Z. 2018. The influencing factors on the level of accrual accounting adoption: A conceptual approach. Romanian Economic Business Review, 13(2), 3036.

Aswar, K., Saidin, S.Z. 2018b. Accrual accounting adoption in Java Municipalities: an empirical investigation. International Journal of Business and Economic Sciences Applied Research, 11(3), 24-30.

Aswar, K. 2019. Factors on the accrual accounting adoption: Empirical evidence from Indonesia. International Journal of Business and Economic Sciences Applied Research, 12(3), 36-42.

Behn, R.D. 2003. Why measure performance? different purposes require different measures. Public Administration Review, 63(5), 586-606.

Cavalluzzo, K.S., Ittner, C.D. 2004. Implementing performance measurement innovations: evidence from government. Accounting, Organizations and Society, 29(3-4), $243-$ 267.

DiMaggio, P.J., Powell, W.W. 1983. The iron cage revisited: institutional isomorphism and collective rationality in organizational fields. American Sociological Review, 48(2), 147-160.

Fernandez, S., Rainey, H.G. 2006. Managing successful organizational change in the public sector. Public Administration Review, 66(2), 168-176.

Gudono. 2012. Analisis data multivariat (multi variate data analysis). Yogyakarta: BPFE UGM.

Hatry, H.P. 1999. Performance measurement: getting results. Washington, DC: Urban Institute Press.

Imawan, R. 2005. Desentralisasi, demokrasi, dan pembentukan good governance desentralisasi dan otonomi daerah. Jakarta: LIPI Press. 
Julnes, P., Holzer, M. 2002. Promoting the utilization of performance measures in public organizations: an empirical study of factors affecting adoption and implementation. Public Administration Review, 61(6), 693-708.

Jurnali, T., Siti-Nabiha, A.K. 2015. Performance management system for local government the Indonesian experience. Global Business Review, 16(3), 351-363.

Kloot, L. 1999. Performance measurement and accountability in Victorian local government. The International Journal of Public Sector Management, 12(7), 565-583.

Moynihan, D.P. 2005. Why and how do state governments adopt and implement "managing for results" reforms? Journal of Public Administration Research and Theory, 15(2), 219-241.

Moynihan, D.P., Pandey, S.K. 2010. The big question for performance management: why fo managers use performance information? Journal of Public Administration Research and Theory, 20(4), 849-866.

Muhammad, N.M., Jantan, M., Md Taib, F. 2010. Moderating effect of information processing capacity to investment decision making and environmental scanning. Business Management Quarterly Review, 1(1), 9-22.

Newcomer, K., Jennings, E., Broom, C., Lomax, A. 2002. Meeting the challenges of performance-oriented government. Washington, DC., American Society for Public Administration.

Pallant, J. 2005. SPSS Survival Manual: A Step by Step Guide to Data Analysis using SPSS for Windows (Version 12).

Primasanti, H., Akbar, R. 2015. Factors influencing the success of performance measurement: evidence from local government. Journal of Indonesian Economy and Business, 30(1), 56-71.

Propper, C., Wilson, D. 2003. The use and usefulness of performance measures in the public sector. Oxford Review of Economic Policy, 19(2), 250-265.

Rainey, H.G. 2003. Understanding and managing public organizations (3rd ed.). San Fransisco, CA., Jossey-Bass.

Scott, W.R. 1987. The adolescence of institutional theory. Administrative Science Quarterly, 32(4), 493-511.

Scott, W.R. 2004. Institutional theory: contributing to a theoretical research program. Oxford: Oxford University Press.

Shields, M.D. 1995. An empirical analysis of firms implementation experiences with activitybased costing. Journal of Management Accounting Research, 7(1), 140-166.

Wang, X., Berman, E. 2000. Hypotheses about performance measurement in counties: finding from a survey. Journal of Public Administration Research and Theory, 11(3), 403428.

Wijaya, A.H.C., Akbar, R. 2013. The influence of information, organizational objectives and targets, and external pressure towards the adoption of performance measurement system in public sector. Journal of Indonesian Economy and Business, 28(1), 62-83.

Yang, K., Hsieh, J.Y. 2007. Managerial effectiveness of government performance measurement: Testing a middle-range model. Public Administration Review, 67(5), 861-879. 